\title{
Variation in Soil Properties along a Catena in kwambai Taraba State, Nigeria
}

\author{
Mbashak. R ${ }^{1 *}$, Garjila A.Y2, Gideon $\mathrm{PK}^{3}$, Yakubu N Y ${ }^{4}$, Rikin M.L ${ }^{1}$ \\ ${ }^{1 *}$ Department of Crop Science, College of Agriculture P.M.B.1025 Jalingo Taraba State,Nigeria. \\ ${ }^{2}$ Department of Agronomy,Federal University of Kashere,PMB 0182,Go mbe StateNigeria. \\ ${ }^{3}$ Department of Forestry College of Agriculture P.M.B.1025 Jalingo Taraba State ,Nigeria. \\ ${ }^{4}$ Department of Bioproduction National Biotechnology Development Agency Jalingo, Taraba State Nigeria.
}

Abstract-The study was carried out to determine the variation in soil properties within units and along a catena, significant of variation to soil mapping and soil management at kwambai, Takum, within latitude $705 \mathrm{~N}$ and longitude 905 D E to 10 o 10oE.Taraba State. Soil sample were collected from upland, slope and lowland areas of the catena at the depth of $0-15 \mathrm{~cm}$ and $15-30 \mathrm{~cm}$ at 3 composite, 18 samples were collected. Soil properties analyzed include $\mathrm{pH}$, Total Acidity $\mathrm{EC}(\mathrm{dS} / \mathrm{m}), \mathrm{Ca}(\mathrm{Meg} / \mathrm{Kg})$, $\mathrm{Mg}(\mathrm{Meg} / \mathrm{Kg}, \mathrm{K}(\mathrm{Meg} / \mathrm{Kg}), \mathrm{Na}(\mathrm{Meg} / \mathrm{Kg})$, Base saturation\%, TEB $(\mathrm{Meg} / \mathrm{Kg}) \quad \mathrm{ECEC}(\mathrm{Meg} / \mathrm{Kg}), \quad \mathrm{P}(\mathrm{ppm}), \quad \mathrm{N} \%, O . C \%, C: N$ ratio. Sand has the highest fraction in the soil. The soil is predominantly sandy clay loam. Clay loam in lowland surface, loam and sandy clay are less according to textural class. Grayish brown dominate the soil, dull brown in upland subsurface, others are brown, orange, and brownish grey.In upland area $E C, C a, M g, T E B, N$ and $O C$ decrease with depth while others increase with depth. In slope area Total acidity, Ca, Mg, TEB, ECEC and P Increase with depth while others decrease with depth. In Lowland area $\mathrm{Ca}, \mathrm{Mg}, \mathrm{Na}$, TEB, Base saturation, ECEC, and N Increase while others decrease with depth There is Significance differences in soil properties down the catena. There is no change in EC. C:N ratio has the highest coefficient of variation of $40.8 \%$ while base saturation has the lowest with $1.2 \%$ in surface down the catena, the highest in subsurface is total acidity with $55.5 \%$ and the lowest is $C: N$ ratio with $1.0 \%$. The following recommendations were made. More samples to be collected during Mapping, the area interval should be reduced. Management can be easily be done in the soil. Application of lime to correct soil acidity should be moderate; fertilizer application should be not be uniform because of variation in the Landscape area. Keywords-Catena, Variation, depth, Mapping, management, properties.

\section{INTRODUCTION}

One of the major problem of soils often ignored by soil scientists is soil variation is no stranger to a penologist since the very essence of his profession dates back to the early recognition that soil are systematically related to landscape. The variation of soil properties affects soil Performance in that a uniform application of treatment in

especially variable soil results in over-application in some parts of the field and under application in others. Cambardella,C.A \& K Karlen,D.L.(1999).Details characterization of soils and their variation along different topography positions has not been investigated in depth Butros I. Hatter et.al (2010).Soil as a natural body is inherently heterogeneous because of the many factors that contribute to soil formation and the complex interactions of those factors, L.M.Maniyunda ,et al;(2015). Variability of soil properties may be attributed to several sources. Apart from inherent soil differences, variation in soil properties are due to soil forming factors(climate, parents materials, organisms, relief and time)and differences in weathering rates M.Mzuku,R.Khosla et.al (2005).

Mapping of soil properties is an important role in the knowledge about soil properties and how it can be use sustainable, O.A.Denton et.al (2017).If the top soil $\mathrm{pH}$ is above 5.5surface and subsurface is above 4.8 only maintenance level of liming is require, Bolland M.et.al (2004).Soil organic carbon accounts for less than 5\% on soil layers and diminishes with depth, soil

organic carbon can be greater than $10 \%$ while the poorer or heavily exploited soils level are lively to be less than $1 \%, \mathrm{R}$ A. Webster et.al (2014.)Carbon to Nitrogen $(\mathrm{C}: \mathrm{N})$ ratio is often used as a determinant for the health of a soil, $\mathrm{Xu}$ et.al (2016).The bulk of soil fungi and bacteria are found to be concentrated in the surface $10 \mathrm{~cm}$ of the soil as there is high availability of SOM and oxygen(Brady and Weil,2002) P is medium along a catena in soil in Yola Adamawa state, Emmanuel A et.al (2018) 


\section{MATERIALS AND METHODS}

\subsection{Study Area}

The study area is located within latitude $705 \mathrm{~N}$ and longitude $9 \mathrm{o} 5 \mathrm{D}$ E to $10 \mathrm{o}$ 10oE Takum local government area is located in southern Taraba state. It share boundary with Donga to the North, Ussa to the west, Benue and Cameroon to the south and Wukari to the East.Total land mass is $45 \mathrm{~km} 2$ with the population of 135,349 according to 2006 Census.

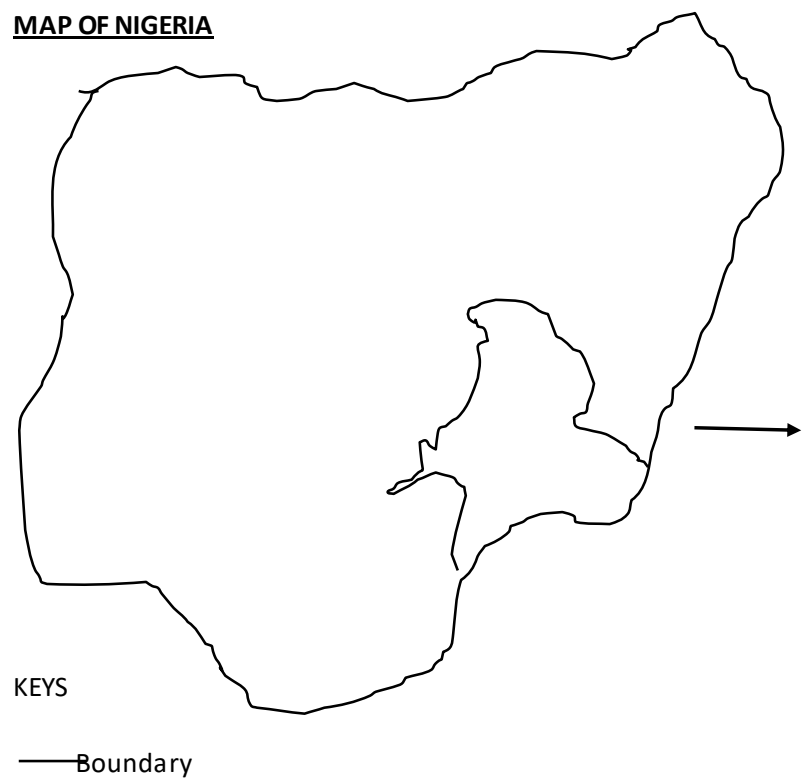

Study Area(Kwambai)

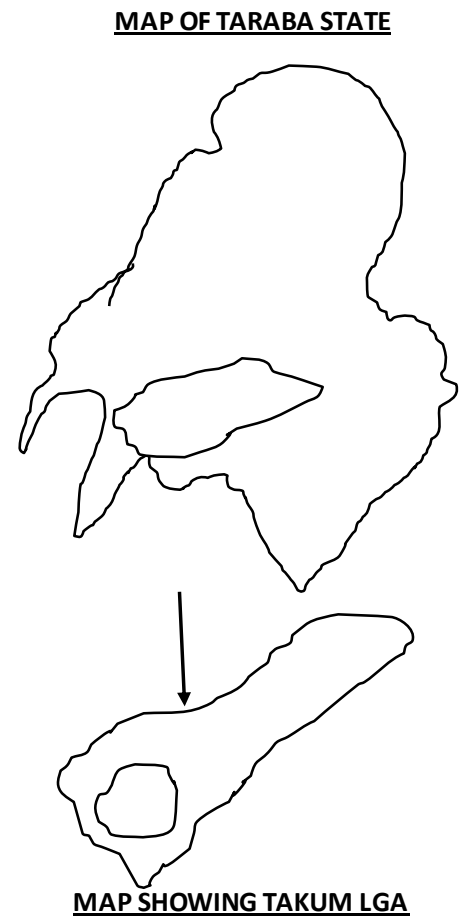

Fig.1: Showing the location of the study area

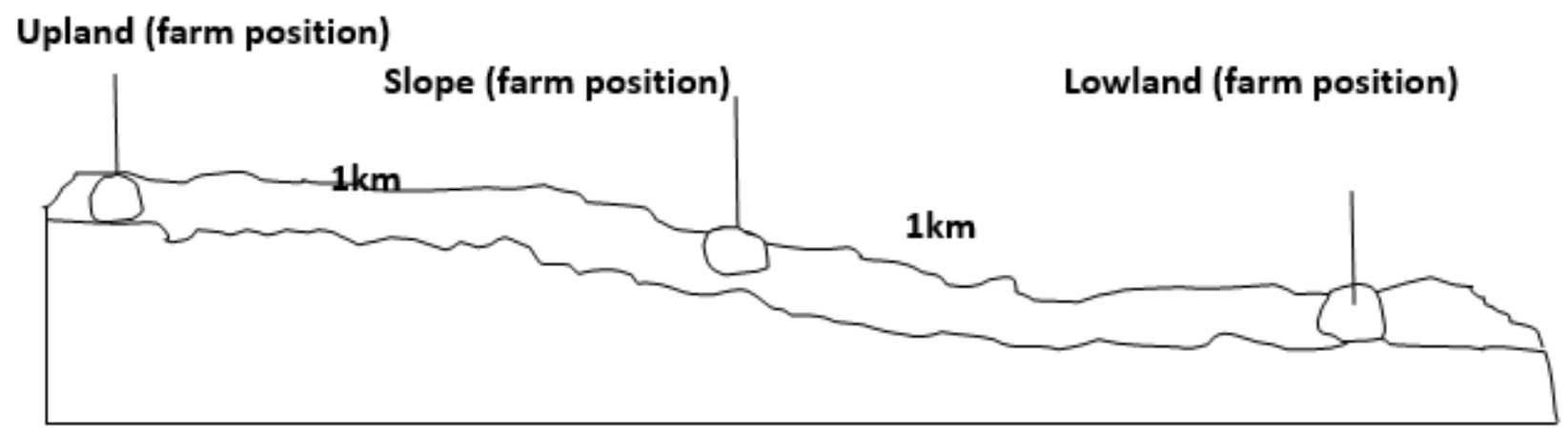

Fig.2. Landscape, farm position of the study area

Climate; Raining season start march and end October, dry season reach it peak in January and February when the dusty North east trade wind blow across the area. The annual temperature range from $27^{\circ} \mathrm{C}$ to $31^{\circ} \mathrm{C}$.the climate of the study area provide conducive atmosphere for cultivation of most stable food. The area has a rainfall of 2000 to $2500 \mathrm{~mm}$. Vegetation of the study area is Guinea savannah which is made up of dense grasses and trees. Topography of the study area, has a gentle slope. The angle of the slope is about $8^{\circ}$ using abney level. The relief of the area favour rainfall and temperature.

\section{2:2 Sampling Procedure}

Field work reconnaissance survey was carry out to identify a representative landscape in the catena, in Kwambai area of Takum local government of Taraba state landscape position such as upland, slope and lowland were located. For the propose of this study three location or intervention sites chosen within the landscape positions with interval of 
$1 \mathrm{~km}$ each. This was base on the level of farming activities.

Samples were collected at two depths (0-15 cm) and (15-30 $\mathrm{cm}) 3$ composite was located in each landscape position. The total of 18 samples were collected in the landscape position kwambai.

\subsection{Laboratory Analysis}

The soil samples were air-dried for 24-28 hours, crushed and passed through a $2 \mathrm{~mm}$ sieve. Sample from sieve were collected with labeled put inside include site location, survey number and laboratory numbers. Soil sample were analyzed for $\mathrm{pH}$ in both water and $0.01 \mathrm{~m}$ potassium chloride solution(1:1) using glas s electrode $\mathrm{pH}$ meter. Total nitrogen was determined by the macrokjeldahl digestion method,

available phosphorous (Av P) was

determined using Olsen's extraction method UV/visible Spectrometer. Available $\mathrm{K}$ is part of the exchangeable bases ,the exchangeable bases $\left(\mathrm{Ca}^{2+} \mathrm{Mg}^{2+} \mathrm{K}^{+}\right.$and $\left.\mathrm{Na}^{+}\right)$were measured by atomic absorption spectrophotometer after extraction with ammonium acetate at $\mathrm{pH}$ 7.OC samples were titrated using $0.5 \mathrm{~N} \mathrm{FeSO}_{4}$ deep bottle green colour as end point. Hydrometer method was used to determine the particle size distribution. The cation exchange capacity (CEC) was determined by

extraction with ammoniumacetate .percentage base saturation was calculated by dividing the sum of the charge equivalents of the base cations by CEC of the soil and multiplying by 100. Total acidity was determine through titration .EC was taking using EC meter. TEB is the sum of exchangeable cation in the soil.C:N This is when Organics carbon divided by nitrogen.

\section{RESULTS AND DISCUSSION}

Table 1 In particle size distribution Sand is high range from (44.25-61) ,clay(19.70-36.75) and silt(6.55-34.45).it follows the same train in Slope sand(44.6-65.05), Clay(30.35-36.95) and silt(12.4-20.6) and

lowland sand(38.2-53.85), clay(31.6-39.00) and silt(14.5527.00). There is medium variation of particle size distribution down the catena.

Textural class Shows that sandy clay loam is more in the catena, leaving clay loam for lowland surface and small part of upland subsurface and slope .Sandy clay occupied little space in upland subsurface and low land subsurface .little loam in Upland surface.

Surface has more grayish brown and then light brown red, subsurface has more dull orange and then dull brown. Slope surface has brown, dull brown, and grayish brown, subsurface has more orange and then bright brown. Lowland surface has grayish brown, brownish grey and grayish grey, subsurface has more grayish brown and then brownish grey. The catena has more grayish brown

Table.1: soil texture class and color

\begin{tabular}{|c|c|c|c|c|c|}
\hline \multirow[t]{2}{*}{ Landscape position } & \multicolumn{3}{|c|}{ Particles Size distribution\% } & \multirow[t]{2}{*}{ Texture class } & \multirow[t]{2}{*}{ Soil color } \\
\hline & Sand & Silt & Clay & & \\
\hline \multicolumn{6}{|l|}{ Upland surface } \\
\hline $0-15 \mathrm{~cm}$ & 44.25 & 22.55 & 33.70 & Sandy clay loam & 7.5 YR 5/2 grayish brown \\
\hline $0-15 \mathrm{~cm}$ & 45.85 & 34.45 & 19.70 & Loam & 7.5 YR 7/2 Light brown red \\
\hline $0-15 \mathrm{~cm}$ & 61.85 & 6.55 & 31.6 & Sandy clay loam & 7.5 YR 5/2 grayish brown \\
\hline \multicolumn{6}{|l|}{ Subsurface } \\
\hline $15-30 \mathrm{~cm}$ & 49.4 & 15.8 & 34.8 & Sandy clay loam & 7.5 YR $6 / 3$ dull brown \\
\hline $15-30 \mathrm{~cm}$ & 45.85 & 17.4 & 36.75 & Clay loam & 7.5 YR 6/4 dull brown \\
\hline $15-30 \mathrm{~cm}$ & 49.05 & 14.55 & 36.4 & Sandy clay & 7.5 YR 6/4 dull brown \\
\hline \multicolumn{6}{|l|}{ Slope surface } \\
\hline $0-15 \mathrm{~cm}$ & 46.20 & 20.6 & 33.2 & Sandy clay loam & 7.5YR $6 / 3$ brown \\
\hline $0-15 \mathrm{~cm}$ & 65.05 & 16.0 & 33.35 & Sandy clay loam & 7.5YR 6/3 DULL brown \\
\hline $0-15 \mathrm{~cm}$ & 44.6 & 20.6 & 34.8 & Clay loam & 7.5 YR 4/2 grayish brown \\
\hline \multicolumn{6}{|l|}{ subSurface } \\
\hline $15-30 \mathrm{~cm}$ & 52.25 & 17.4 & 30.35 & Sandy clay loam & 7.5 YR $6 / 6$ orange \\
\hline $15-30 \mathrm{~cm}$ & 50.65 & 12.4 & 36.95 & Sandy clay loam & 7.5 YR $6 / 6$ orange \\
\hline $15-30 \mathrm{~cm}$ & 49.05 & 14.53 & 36.95 & Sandy clay loam & 7.5YR 5/6 bright brown \\
\hline \multicolumn{6}{|l|}{ Lowland surface } \\
\hline $0-15 \mathrm{~cm}$ & 41.05 & 19.95 & 36.4 & Clay loam & 7.5 YR 4/2 grayish brown \\
\hline $0-15 \mathrm{~cm}$ & 42.05 & 19.35 & 39 & Clay loam & 7.5 YR 5/1 brownish grey \\
\hline $0.15 \mathrm{~cm}$ & 42.65 & 27 & 38 & Clay loam & 7.5 YR 5/2 grayish grey \\
\hline
\end{tabular}




\section{Subsurface}

$15-30 \mathrm{~cm}$

$15-30 \mathrm{~cm}$

38.2

$15-30 \mathrm{~cm}$
45.5

53.85

\begin{tabular}{ll}
18.1 & 36.4 \\
17.75 & 34.8 \\
14.55 & 31.6 \\
\hline
\end{tabular}

Sandy clay

Sandy clay loam

Sandy clay loam
7.5 YR 5/1 brownish grey

7.5 YR 5/1 grayish brown

7.5 YR 5/1 grayish brown
Table 2 shows that pHs in upland area are slightly acidic increasing with depth, in slope and lowland area, $\mathrm{pH}$ are moderate and decrease with depth. Maintenance level of liming is require because the $\mathrm{pH}$ is above 5.5 in upland and above 4.8 in subsurface .this is with the conformation with Bolland M. et'al (2004)

Total acidity is moderate in upland, slope and lowland. Upland and slope increase with depth while lowland decrease with depth.

EC in upland, slope and lowland are medium. Upland and slope is unsuitable with moderately leaching and slightly decrease with depth, lowland is low and remain the same with depth.

Exchangeable base, $\mathrm{Ca}$ is moderate in upland, slope and lowland. it may be due to plant uptake or leaching. Upland decrease with depth, while slope and lowland increase with depth. $\mathrm{Mg}$ is high in upland area and decrease with depth. $\mathrm{Mg}$ is low in slope surface and high in subsurface. It is high in lowland and increase with depth .K is moderate in upland and it increase slightly with depth .k is moderate in slope and high in lowland (it may be as a result runoff) slope and lowland decrease with depth. $\mathrm{Na}$ increase with depth in upland and lowland area $\mathrm{Na}$ is high in lowland and it decrease with depth in slope. Exchangeable base fall mostly within low and medium range. Confirmation with (Brady and Weil,2002)this may be due to low decomposition of organic matter and slow release of chemical element into the soil. Base saturation slightly increases with depth in upland and low land. it decrease with depth in slope.

TEB and ECEC increase with depth in slope and lowland.TEB decrease while ECEC increases with depth .They are not medium. This is different with the finding of (Emmanuel A et.al 2018).P fall within medium, confirmation with (Emmanuel A et.al 2018) Who observed that $\mathrm{P}$ in the soil of some selected farmland located at Modibbo Adama University Adamawa State shows that $\mathrm{P}$ is medium., $\mathrm{P}$ increase with depth in upland and decrease with depth in slope and lowland it confirm the increase in upland but contradict decrease in slope and lowland (Osujieke et.al 2016) .OC is medium (FDLAR 2012),OC decrease with depth in upland,slope and lowland. this is confirmation with (Brady and Weil,2002) that The bulk of soil fungi and bacteria are found to be concentrated in the surface $10 \mathrm{~cm}$ of the soil as there is high availability of SOM and oxygen. Organic carbon is high in upland and lowland. it is low in the slope, it may be due to plant uptake, rain and runoff down the catena. It is also with agreement with those observed by (Emmerson WW.1991).Nitrogen is low down the Catena 1(FDLAR 2012).N decrease with depth in upland ,slope and increase with depth in lowland area. C:N ratio increase with depth in upland, decrease with depth in slope and lowland. it may be due to leaching or plant uptake.

Table.2: Physio Chemical properties

\begin{tabular}{|c|c|c|c|c|c|c|c|c|c|c|c|c|c|c|c|}
\hline $\begin{array}{l}\text { Landscape } \\
\text { Position }\end{array}$ & $\begin{array}{l}\text { pH } \\
1: L S \\
H_{20}\end{array}$ & $\begin{array}{l}\text { Total } \\
\text { acidity }\end{array}$ & $\begin{array}{l}\mathrm{EC} \\
(\mathrm{dS} / \mathrm{m})\end{array}$ & Exch & seable & nolekg & $\mathrm{Na}$ & $\begin{array}{l}\text { Base } \\
\text { Saturatio } \\
\text { n(\%) }\end{array}$ & $\begin{array}{l}\text { TEB } \\
\text { (Meg/kg) }\end{array}$ & $\begin{array}{l}\text { ECEC } \\
\left(\text { emoleKg }^{-1}\right)\end{array}$ & $\begin{array}{l}\text { P(MegKg } \\
\text { ) }\end{array}$ & $\mathbf{N}(\%)$ & $\mathrm{OC}(\%)$ & C:N & $\begin{array}{l}\text { Textur } \\
\text { e Class }\end{array}$ \\
\hline \multicolumn{16}{|l|}{ Upland } \\
\hline Surface & 6.25 & 0.30 & 231 & 5.60 & 3.00 & 0.37 & 0.13 & 96.8 & 9.10 & 9.10 & 18.00 & 0.45 & 1.07 & 2.38 & SCL \\
\hline $0-15 \mathrm{~cm}$ & 6.36 & 0.30 & 261 & 3.40 & 6.40 & 0.29 & 0.16 & 94.4 & 10.2 & 10.8 & 15.20 & 0.58 & 1.30 & 2.24 & $\mathrm{~L}$ \\
\hline $0-15 \mathrm{~cm}$ & 6.18 & 0.40 & 280 & 3.20 & 4.60 & 0.32 & 0.20 & 98.3 & 8.12 & 8.52 & 17.90 & 0.48 & 1.11 & 2.31 & SCL \\
\hline \multicolumn{16}{|l|}{$0-15 \mathrm{~cm}$} \\
\hline \multicolumn{16}{|l|}{ Subsurface } \\
\hline $15-30 \mathrm{~cm}$ & 6.40 & 0.60 & 261 & 3.80 & 4.40 & 0.42 & 0.15 & 93.6 & 8.78 & 9.38 & 16.50 & 0.33 & 0.83 & 2.58 & SCL \\
\hline $15-30 \mathrm{~cm}$ & 5.93 & 0.30 & 251 & 4.40 & 4.40 & 0.36 & 0.20 & 96.9 & 9.36 & 9.66 & 17.50 & 0.45 & 1.11 & 2.47 & $\mathrm{CL}$ \\
\hline $15-30 \mathrm{~cm}$ & 6.85 & 0.20 & 241 & 4.80 & 2.00 & 0.36 & 0.20 & 97.4 & 7.36 & 7.56 & 19.20 & 0.36 & 0.82 & 2.28 & $\mathrm{SC}$ \\
\hline \multicolumn{16}{|c|}{ Slope Surface } \\
\hline $0-15 \mathrm{~cm}$ & 6.95 & 0.30 & 281 & 2.40 & 2.40 & 0.43 & 0.16 & 94.7 & 5.59 & 5.69 & 13.15 & 0.25 & 0.75 & 2.20 & SCL \\
\hline $0-15 \mathrm{~cm}$ & 5.98 & 0.20 & 230 & 2.80 & 3.80 & 0.47 & 0.24 & 97.1 & 6.84 & 7.04 & 14.2 & 0.28 & 0.66 & 2.36 & SCL \\
\hline $0-15 \mathrm{~cm}$ & 5.62 & 0.30 & 245 & 3.80 & 2.60 & 0.39 & 0.20 & 95.9 & 6.99 & 7.29 & 14.5 & 0.53 & 1.13 & 2.13 & $\mathrm{CL}$ \\
\hline \multicolumn{16}{|l|}{ Subsurface } \\
\hline $15-30 \mathrm{~cm}$ & 5.10 & 0.30 & 242 & 2.80 & 3,60 & 0.38 & 0.15 & 95.8 & 6.89 & 7.21 & 13.5 & 0.22 & 0.59 & 2.68 & SCL \\
\hline $15-30 \mathrm{~cm}$ & 5.95 & 0.40 & 233 & 5.80 & 5.20 & 0.51 & 0.19 & 96.7 & 11.7 & 12.1 & 20.0 & 0.25 & 0.57 & 2.28 & SCL \\
\hline $15-30 \mathrm{~cm}$ & 6.93 & 0.70 & 205 & 2.40 & 5.40 & 0.29 & 0.20 & 92.2 & 8.29 & 8.99 & 12.2 & 0.17 & 0.39 & 2.29 & SCL \\
\hline
\end{tabular}




\begin{tabular}{|c|c|c|c|c|c|c|c|c|c|c|c|c|c|c|c|}
\hline \multicolumn{16}{|l|}{ Lowland } \\
\hline \multicolumn{16}{|l|}{ Surface } \\
\hline $0-15 \mathrm{~cm}$ & 6.31 & 0.30 & 227 & 2.60 & 7.00 & 0.46 & 0.16 & 97.1 & 10.2 & 10.5 & 17.8 & 0.42 & 1.14 & 2.36 & $\mathrm{CL}$ \\
\hline $0-15 \mathrm{~cm}$ & 5.91 & 0.50 & 250 & 2.40 & 2.00 & 0.38 & 0.24 & 90.9 & 5.02 & 5.52 & 16.5 & 0.36 & 0.80 & 2.22 & CL \\
\hline $0-15 \mathrm{~cm}$ & 5.38 & 0.20 & 235 & 4.00 & 4.40 & 0.59 & 0.20 & 97.8 & 9.19 & 9.39 & 20.3 & 0.19 & 1.09 & 4.41 & $\mathrm{CL}$ \\
\hline \multicolumn{16}{|c|}{ Subsurface } \\
\hline $15-30 \mathrm{~cm}$ & 5.83 & 0.40 & 210 & 2.80 & 4.80 & 0.36 & 0.20 & 95.3 & 8.16 & 8.56 & 14.3 & 0.45 & 1.10 & 2.44 & $\mathrm{SC}$ \\
\hline $15-30 \mathrm{~cm}$ & 5.85 & 0.30 & 227 & 3.20 & 5.80 & 0.47 & 0.24 & 97.1 & 9.71 & 10.1 & 17.5 & 0.28 & 0.50 & 2.03 & SCL \\
\hline $15-30 \mathrm{~cm}$ & 5.81 & 0.20 & 275 & 4.80 & 4.00 & 0.37 & 0.24 & 97.7 & 9.41 & 6.61 & 19.0 & 0.53 & 1.11 & 2.09 & SCL \\
\hline
\end{tabular}

KEY:L=LOAM, CL=CLA Y LOAM,SC=SANDY CLAY,SCL=SANDY CLAY LOAM.

\subsection{Trend in soil properties down a catena} (mean and CV\%)

From table $3, \mathrm{pH} \quad$ surface $(6.26>6.18>5.86) \quad$,and subsurface $(6.36>5.98>5.83)$ Aweto A.O and Enaruvbe G.O (2010)The decline in soil $\mathrm{pH}$ is partly due to the decline of Exchangeable cations,especially especially magnesium, and base saturation. Total acidity surface $(0.33>0.26<0.33)$ and subsurface $(0.36<0.46>0.30)$. Soil properties are not always uniform in all the segment of the catena kravchenko and Bullock( 2000). EC,surface(2.57>2.52>2.32) and subsurface $(2.56>2.27<2.37)$, Ca surface $(4.06>3.00=3.00)$ it may be due to exploitation through farming or leaching in slope and lowland. subsurface $(3.56<3.66>3.60), \quad \mathrm{Mg}$ surface $(4.66>2.90<4.46) \quad$ subsurface $\quad(3.16<4.73<4.86) \quad \mathrm{K}$ surface $(0.32<0.43<0.47)$ it may be due to water runoff from the upland. Subsurface $\quad(0.38=0.38<0.40) \quad$,Na surface $(0.16<0.20=0.20)$ and subsurface $(0.18=0.18<0.22)$, base Saturation surface $(96.5<95.9<96.7) \quad$ subsurface (95.9>94.9<96.7,TEB $\quad$ surface $(9.14>6.40<8.13) \quad$ and subsurface $(8.5<8.96<9.09)$.ECEC $\quad$ surface $(9.57>6.60<8.47)$ and subsurface

$(8.86<9.43<9.44), \mathrm{P} \quad$ surface $(17.03>13.9>8.2) \quad$ and subsurface $(17.66>15.2<16.9), \mathrm{N}$ surface $(0.50>0.35>0.32)$ subsurface $\quad(0.38>0.21<0.42)$. The total Nitrogen shows Variation in descending in surface, but not descending or ascending order in

Subsurface According to Majawliwa et.al (2015) ,OC surface $(1.16>0.84<1.01) \quad$ subsurface $\quad(0.92>0.15<0.92) \quad$ C:N $(2.31>2.23<2.99)$ and subsurface $(3.37>2.14<2.18)$.

Coefficient of variation in Surface C:N and N (2.942.8\%), $\mathrm{Ca}$ and $\mathrm{Mg},(24-36.4 \%), \mathrm{OC}$ and ECEC (10.3$30.8 \%) . \mathrm{K}, \mathrm{Na}$ and $\mathrm{TEB},(9.3-21.2 \%)$ are medium, Base saturation(1.2-3.9\%),Ec and $\mathrm{pH}(1.4-11 \%) \mathrm{P}$ and Total

Acidity (9.2-19.2\%) are low. In subsurface Total acidity and $\mathrm{Mg}(11.5-55.5 \%)$ have high variation. $\mathrm{K}, \mathrm{P}, \mathrm{N}, \mathrm{OC}, \mathrm{ECEC}$, $\mathrm{Ca}$ and TEB (7.8-32.6\%) have Medium variation. Ec and $\mathrm{Na}(3.9-15.5 \%)$, C:N,Base Saturation and $\mathrm{pH}(1.0-9.1 \%)$ have low variation along a catena.

Table.3: Variation of soil properties across the catena(Mean and CV\%)

\begin{tabular}{|c|c|c|c|c|c|c|c|}
\hline \multirow[t]{2}{*}{ Variables } & \multirow[t]{2}{*}{ Properties } & \multicolumn{2}{|c|}{ Upland } & \multicolumn{2}{|l|}{ Slope } & \multicolumn{2}{|c|}{ Lowland } \\
\hline & & Mean & $\mathrm{CV} \%$ & Mean & $\mathrm{CV} \%$ & Mean & $\mathrm{CV} \%$ \\
\hline \multirow[t]{14}{*}{ Surface $(0-15 \mathrm{~cm})$} & $\mathrm{Ph}$ & 6.26 & 1.4 & 6.18 & 11 & 5.86 & 7.8 \\
\hline & Total Acidity & 0.33 & 15.2 & 0.26 & 19.2 & 0.33 & 19.2 \\
\hline & $\mathrm{EC}(\mathrm{dS} / \mathrm{m})$ & 2.57 & 9.3 & 2.52 & 10.3 & 2.37 & 4.6 \\
\hline & $\mathrm{Ca}(\mathrm{Meg} / \mathrm{Kg})$ & 4.06 & 29.0 & 3.00 & 32.7 & 3.00 & 24 \\
\hline & $\mathrm{Mg}(\mathrm{Meg} / \mathrm{Kg})$ & 4.66 & 25.6 & 2.90 & 29.0 & 4.46 & 36.4 \\
\hline & $\mathrm{K}(\mathrm{Meg} / \mathrm{Kg})$ & 0.32 & 12.5 & 0.43 & 9.3 & 0.47 & 21.2 \\
\hline & $\mathrm{Na}(\mathrm{Meg} / \mathrm{Kg})$ & 0.16 & 16.6 & 0.20 & 2.0 & 0.20 & 20.0 \\
\hline & Base saturation $\%$ & 96.5 & 2.0 & 95.9 & 1.2 & 95.2 & 3.9 \\
\hline & TEB(Meg/Kg) & 9.14 & 11.3 & 6.40 & 13.7 & 8.13 & 33.7 \\
\hline & ECEC(Meg/Kg) & 9.57 & 11.9 & 6.60 & 12.8 & 8.47 & 30.8 \\
\hline & $\mathrm{P}(\mathrm{ppm})$ & 17.03 & 9.2 & 13.9 & 5.0 & 18.2 & 10.6 \\
\hline & $\mathrm{N} \%$ & 0.50 & 12.0 & 0.35 & 42.8 & 0.32 & 36.3 \\
\hline & $\mathrm{O} . \mathrm{C} \%$ & 1.16 & 10.3 & 0.84 & 28.5 & 1.01 & 17.8 \\
\hline & $\mathrm{C}: \mathrm{N}$ ratio & 2.31 & 2.9 & 2.23 & 4.9 & 2.99 & 40.8 \\
\hline \multirow[t]{5}{*}{ Subsurface(15-30) } & $\mathrm{Ph}$ & 6.36 & 7.1 & 5.98 & 3.8 & 5.83 & 3.4 \\
\hline & Total Acidity & 0.36 & 55.5 & 0.46 & 43.4 & 0.30 & 38.3 \\
\hline & $\mathrm{EC}(\mathrm{dS} / \mathrm{m})$ & 2.56 & 3.9 & 2.27 & 8.4 & 2.37 & 13.9 \\
\hline & $\mathrm{Ca}(\mathrm{Meg} / \mathrm{Kg})$ & 3.56 & 29.1 & 3.66 & 11.5 & 3.60 & 10.1 \\
\hline & $\mathrm{Mg}(\mathrm{Meg} / \mathrm{Kg})$ & 3.66 & 50.5 & 4.73 & 11.1 & 4.86 & 38.3 \\
\hline
\end{tabular}




\begin{tabular}{lllllll}
$\mathrm{K}(\mathrm{Meg} / \mathrm{Kg})$ & 0.38 & 7.8 & 0.38 & 28.9 & 0.40 & 15.0 \\
$\mathrm{Na}(\mathrm{Meg} / \mathrm{Kg})$ & 0,18 & 15.5 & 0.18 & 11.1 & 0.22 & 9.0 \\
Base saturation\% & 95.9 & 2.1 & 94.9 & 2.5 & 96.7 & 1.3 \\
$\mathrm{TEB}(\mathrm{Meg} / \mathrm{Kg})$ & 8.5 & 12.0 & 8.96 & 27.4 & 9.09 & 9.0 \\
ECEC(Meg/Kg) & 8.86 & 12.8 & 9.43 & 26.1 & 9.44 & 8.2 \\
$\mathrm{P}(\mathrm{ppm})$ & 17.66 & 8.2 & 15.2 & 27.1 & 16.9 & 14.2 \\
$\mathrm{~N} \%$ & 0.38 & 15.7 & 0.21 & 19.0 & 0.42 & 28.5 \\
O.C\% & 0.92 & 17.3 & 0.51 & 21.5 & 0.92 & 32.6 \\
C:N ratio & 3.37 & 6.1 & 2.14 & $9 . \mathrm{I}$ & 2.18 & 1.0 \\
\hline
\end{tabular}

\subsection{Significance Of Soil Variation To Soil Mapping}

There is high and moderate variation of soil properties across the landscape position(catena).The soil change with some meters in confirmation of (Aweto A.O and Enaruvbe G.O 2010) from their finding soil properties are not always uniform in all slope segment of the catena. soil thickness was observed it may be due to heavy implement on the farm or grazing by ruminant animals. In case of sampling more samples should be collected. Sample interval should be reduced preferably small scale.

\subsection{Significant of Soil Variation to Soil Management.}

From table 1 The dominant soil is sandy clay loam then; clay loam, sandy clay and loam. Management can be easily done in the above soil. Application of lime to correct acidity should be maderate. Fertilizer application should not be uniform due to the variation of properties of some landscape area Cambardella,C.A \& Karlen,D.L.(1999). Zero or no tillage should be practice to reduce compaction.

\section{CONCLUSIONS}

Generally the variation in soil properties is moderate within the landscape position of the catena excluding Base saturation, $\mathrm{EC}, \mathrm{pH}, \mathrm{P}$, Total acidity are low in surface while Total acidity and $\mathrm{Mg}$ are high, EC,Na,C:N,

Base Saturation, $\mathrm{pH}$ are low in subsurface. The results indicate that the density of observations for those soil properties exhibiting high and medium variation should be increase during sampling, soil mapping and for soil management purpose.

\section{REFERENCES}

[1] Aweto A.O and Enaruvbe G.O (2010) Centenary variation of soil properties under oil palm plantation in southwestern Nigeria.Ethiopian Journal of environmental studies and management,3(1),1-7.

[2] Bolland M,Gazey C,Miller A,Gartner D and Racher J.(2004) subsurface acidity. Department of Agriculture and food, western, Australia bulletin 4602.

[3] Brady,NC.,Weil,R.R,.2002 the nature and properties of soils(No Ed 13).prentice Hall Inc.
[4] Cambardella,C.A.\&Karlen,D.L(1999).Spacial analysis of soil fertility parameters.precision Agriculture 1,5-14.

[5] Emmers on WW.(1991) Structure decline of soils, assessment and prevention.Australian Journal of Research 29:905-922.

[6] Emmanuel A.HitlerL,Udochukwu AO,Tizhe TF et.al.(2018)assessment of organic carbon and available Nitrogen in the soil of some selected farmlands located at modibbo adama University of Technology, adamawa state ,Nigeria J Environ Anal Chem 5;239.doi:10.4172/2380-2391.1000239.

[7] Federal fertilizer department .Federal Ministery of Agriculture and Rural Development .(2012)fertilizer use and management practices for crops in Nigeria (4thed.,40-41)

[8] Majaliwa,M.Tenywa,M, Karuturi P. C, Bermard.M,Fungo B.(2015)soil fertilityin relation to landscape and position and land use/cover type:a case study of the kivu Pilot Learning site .Advances in Agriculture: Hindawl Publishing corperation.

[9] Maniyunda L M.Raji B.A. Odunze A.C. Malgwe W.B (2015)Form and content of sesquioxidees in soil on basement complexes of northern Guinea savanna of Nigeria.vol6(6) pp.148-157

[10] OsujiekeD.N, Onweremadu.E.U, Ahukaemere C M and Ndukwu B.N (2016) Classification of soil of Australian soil. Global change Biology DOI:10.1111/gcb.125

[11] R.A.Webster, R.Bui .En, Balddock. J A ,2014. baseline map of organic carbon in Whelan. B. and McBratney,A.(2000).the null hypothesis of precision agricultural management. In : precision A6jgriculture ,2, 265-279. 